\title{
A Case of Bilateral Vocal Cord Immobility as a Initial Manifestation of Relapsing Polychondritis
}

\author{
Jin-Yong Kim ${ }^{1}$, Seong-Ki Ahn ${ }^{1,2}$, Jung-Je Park ${ }^{1,2}$ and Jong-Sil Lee ${ }^{3}$ \\ ${ }^{1}$ Departments of Otolaryngology, ${ }^{2}$ Institute of Health Sciences, ${ }^{3}$ Pathology, School of Medicine, Gyeongsang National University, \\ Jinju, Korea
}

\author{
양측 성대 고정을 유발한 재발성 다발성 연골염 1 예 \\ 김진용 ${ }^{1} \cdot$ 안성기 $^{1,2} \cdot$ 박정제 $^{1,2} \cdot$ 이종실 ${ }^{3}$ \\ 경상대학교 의학전문대학원 이비인후과학교실, ${ }^{1}$ 건강과학연구원, ${ }^{2}$ 병리과학교실 ${ }^{3}$
}

\author{
Received January 10, 2011 \\ Revised April 5, 2011 \\ Accepted April 6, 2011 \\ Address for correspondence \\ Seong-Ki Ahn, MD \\ Department of Otolaryngology, \\ School of Medicine, \\ Gyeongsang National University, \\ 79 Gangnam-ro, \\ Jinju 660-702, Korea \\ Tel $+82-55-750-8176$ \\ Fax $+82-55-759-0613$ \\ E-mail skahn@gnu.ac.kr
}

Relapsing polychondritis is a rare multisystem disorder of unknown etiology characterized by episodic recurrent inflammation and degeneration of cartilage and connective tissue. Autoantibodies against cartilaginous collagen may play a crucial role in the pathogenesis of the disease. Laryngotracheobronchial involvements are rare but the most severe manifestations of the diseases. Although uncommon, this disease should be noted and included in a differential diagnosis in patients who complain of difficulty breathing. Along with a review of the related literatures, we report here on an unusual case of bilateral vocal cord immobility as an initial manifestation of relapsing polychondritis.

Korean J Otorhinolaryngol-Head Neck Surg 2011;54:368-71

Key Words Relapsing polychondritis $\cdot$ Auricle $\cdot$ Vocal cords.

\section{서 론}

재발성 다발성 연골염은 전신의 연골 조직과 결합 조직을 침 범하여 파괴시키는 염증성 병변으로, 원인은 분명하지 않으나, 자가면역질환의 일종으로 생각하고 있는 드문 질환이다. 임상 증상으로 이개 연골염이 가장 흔하며, 비배의 연골부를 침범 한 안비 기형, 후두 및 기관지 연골염, 관절염, 눈을 침범한 골 막염이나 결막염을 유발하는 것으로 알려져 있다. ${ }^{1,2)}$ 진단은 다양한 부위에 침범하므로 그에 따른 임상 소견과 병리조직학 적 소견에 의한다. 치료는 대부분 스테로이드제제, 면역억제제 또는 세포독성제와 같은 약물 요법을 시행하여, 만일 호흡 기 관에 이상이 발생하는 경우에는 기관절개술 등과 같은 수술 적 방법을 시행할 수 있다. ${ }^{1,3}$

이러한 재발성 다발성 연골염이 기관, 기관지 또는 후두 부 위와 같은 부위를 침범하면 호흡 곤란을 주 증상으로 올 수 있고, 제일 심한 임상 증상의 형태로 나타난다고 알려져 있으
며 이에 대하여 간헐적으로 보고 ${ }^{3,4}$ 되고 있지만, 국내에서 양 측 성대 고정을 주소로 내원한 다발성 연골염은 보고된 바가 없다. 이에 저자들은 양측 성대 고정으로 인하여 호흡 곤란을 주소로 온 65 세 남자 환자에서 다발성 연골염 1 예를 치험하였 기에 문헌 고찰과 함께 보고하는 바이다.

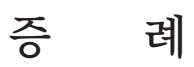

65세 된 남자가 내원 10일 전부터 발생한 음성 변화와 심 한 호흡 곤란을 주소로 본원 응급실로 내원하였다. 내원 당 시 시행한 후두내시경 검사에서 양측 성대는 환자가 흡기 시 에 부정중위(paramedian position)를 보이는 성대 고정 소 견을 보였다(Fig. 1). 내원 당시 촬영한 경부 전산화단층촬영 에서 특이 소견은 관찰되지 않았지만(Fig. 2), 심한 호흡 곤 란과 함께 양측 성대 고정 소견을 보여 응급으로 국소 마취 하에서 기관절개술을 시행하였다. 술 후 양측 성대 고정에 대 


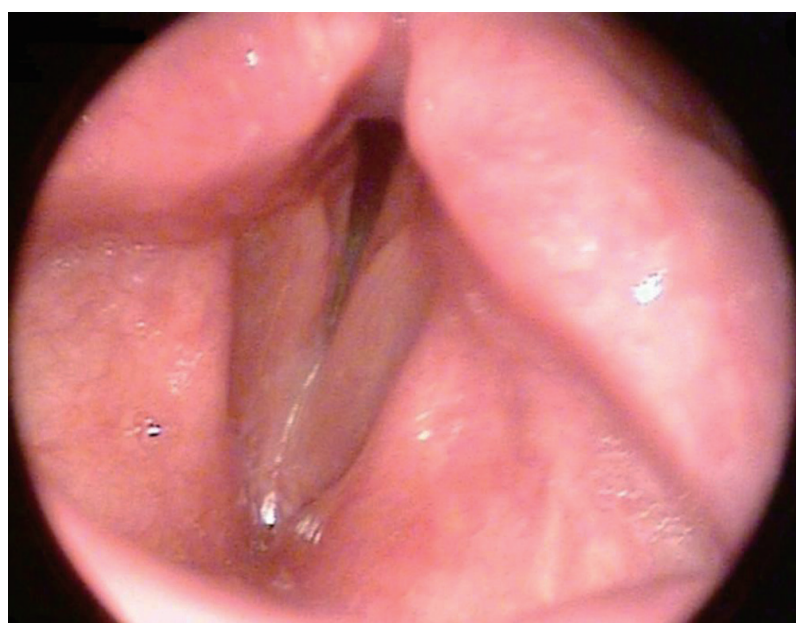

Fig. 1. Laryngoscopic view of the vocal cords at inspiration of the patient. Severe glottic narrowing due to reduced abduction of the vocal folds and normal arytenoid mucosa is shown. There is no mucosal swelling of the both arytenoid cartilages.

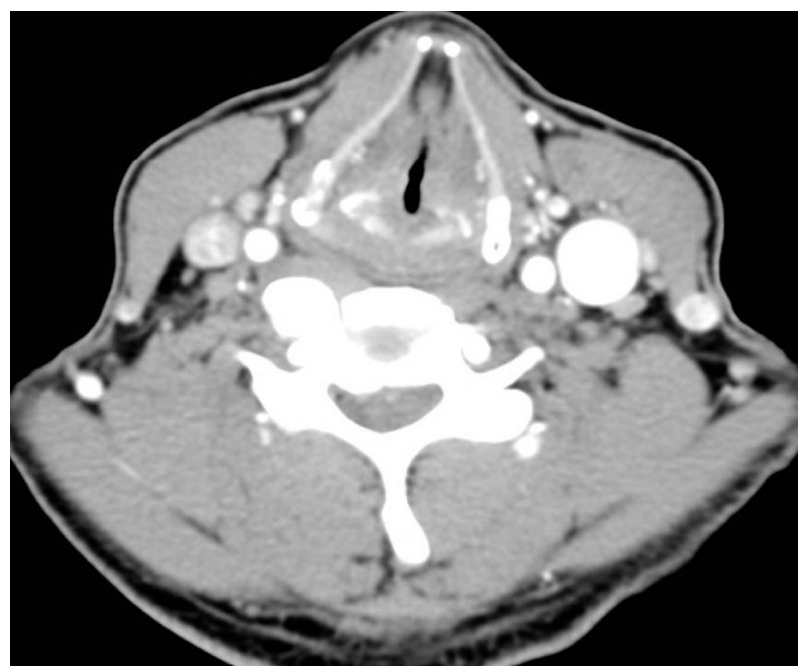

Fig. 2. The neck axial CT scan shows no other specific findings at the level of the vocal cord except for the narrowed airway. CT: computed tomography.

한 중추성 원인을 감별하기 위해 뇌 자기공명영상을 촬영하 였지만 역시 특이 소견을 보이지는 않았다.

당일 시행한 일반혈액 검사에서 백혈구 수치가 $13,370 / \mathrm{mm}^{3}$, 적혈구 침강속도가 $60.2 \mathrm{~mm} / \mathrm{hr}$ 로 증가되어 있었다. 그리고 $\mathrm{C}$-반응성 단백질도 $205.6 \mathrm{mg} / \mathrm{L}$ 로 증가되어 있었고 혈당이 $226 \mathrm{mg} / \mathrm{dL}$ 측정되었다. 기관절개술 후 본원 재활의학과에 의 뢰하여 반회후두신경의 손상에 의한 성대마비 유무를 감별하 기 위하여 후두 근전도를 시행하였으나, 신경 전도상 특별한 문 제점은 관찰되지 않았다. 과거 병력에서 이전의 감기나, 갑상선 수술, 후두부 손상 등의 병력은 없었고 다른 원인을 찾지 못하 여 특발성 양측 성대 고정으로 진단하였고, 대증적인 치료 후 에 호흡 곤란 증상이 많이 호전되어 기관지절개 튜브를 삽입한 채 정기적인 외래경과를 관찰하기로 하고 퇴원하였다.



Fig. 3. The left auricle shows diffuse erythematous swelling, suggesting chondritis.

환자는 3 개월 후 흥통을 주소로 본원 내과로 다시 입원하 여, 경식도 심장 초음파(transesophageal echocardiography)를 시행한 후 확장형 심근병증(dilated cardiomyopathy) 을 진단 받아 입원하였다. 문진에서 환자는 2 개월 전부터 양측 이개 발적과 동통이 있었고, 코 모양이 조금 변한다고 호소하였 고, 재발성 다발성 연골염이 의심되어 이비인후과로 협진 의뢰 가 되었다. 당시 내과에서 측정한 일반혈액 검사상 혈색소가 $19.66 \mathrm{~g} / \mathrm{dL}$ 로 증가하였고, 적혈구 침강속도가 $118 \mathrm{~mm} / \mathrm{hr}$ 로 증가되어 있었다. 보체 C3 $180 \mathrm{mg} / \mathrm{dL}$, 보체 C4 $36.7 \mathrm{mg} / \mathrm{dL}$ 로 정상 소견을 보였다. 이학적 소견으로 양측 이개에 발적과 통증이 있었으며 비배 부위가 조금 낮아졌으나 비강 내는 특 이 소견 관찰되지 않았고 양측 성대고정은 여전히 지속된 소 견을 보였다. 위와 같은 결과들에서 다발성 연골염이 의심되어 국소 마취 하에서 이개 연골 병리조직 검사를 시행하였다(Fig. 3). 병리조직학적 소견상 좌측 이개 연골의 연골막과 연골 주 위조직에 염증세포의 침윤이 증가되고 연골세포는 감소된 소 견을 보여 다발성 연골염으로 진단하였다(Fig. 4). 치료는 재 발성 다발성 연골염 진단 하에 면역 억제제인 azathiprine(50 $\mathrm{mg} /$ day)와 methylprednisolone(60 mg/day)을 2주간 투여 한 후에 양측 이개의 발적과 부종 및 성대 고정 소견도 호전되 어 퇴원하였다(Fig. 5). 현재 외래 통원치료 1년 동안 재발은 보이지 않는 상태이다.

\section{고 찰}

재발성 다발성 연골염은 1923년 Jaksch-Wartenhorst 에 의해 처음 기술된 이래 Pearson 등히이 14예의 환자를 보 고하면서 처음으로 재발성 다발성 연골염으로 명명하였으며, 
Dolan 등히이 특징적인 임상소견을 정리하였다. 이 질환은 40 60대에 주로 발생하지만 전 연령층에 영향을 미치며, 모 든 인종에서 나타날 수 있다. 남·녀 발생비는 비슷하며 가족 력은 없다. 발병 원인은 아직까지 분명하지 않지만, 약 $25 \%$ 에서 다른 류마티스 및 자가면역질환이 동반되는 것으로 보 아 면역기능의 장애가 발병에 관여한다고 알려져 있다. ${ }^{7)}$

임상 증상은 침범하는 부위에 따라 다양하며, 이개, 관절, 코, 눈, 호흡기관, 심장 판막과 피부 순 등으로 침범한다. 드 물지만 외국에서 후두 연골을 먼저 침범한 재발성 다발성 연 골염 1 예가 보고 ${ }^{8}$ 된 적이 있었고, 이 증례에서도 아주 드물 게 호흡기 계통 중에서 후두의 피열 연골을 먼저 침범하여 환자는 호흡곤란을 주소로 내원하였고, 그 이후에 이개 연 골과 비연골의 침범을 한 것으로써 일반적인 증례 보고들과 는 침범 순서가 다르다고 할 수 있다.

진단 기준은 1976년 McAdam등이이 1) 양측 이개 연골염, 2) 다발성 관절염, 3) 비연골염, 4) 결막염, 공막염, 각막염, 또는 포도막염 등의 안염증, 5) 후두와 기관연골 등의 연골 염, 6) 감각신경성 난청, 이명, 또는 현훈 등의 증상 등을 포함 하여 6 가지 진단 기준을 제시하였으며, 이 중에서 3 개 이상의 병변이 있으면서 특징적인 병리조직학적 소견이 있을 때 확진

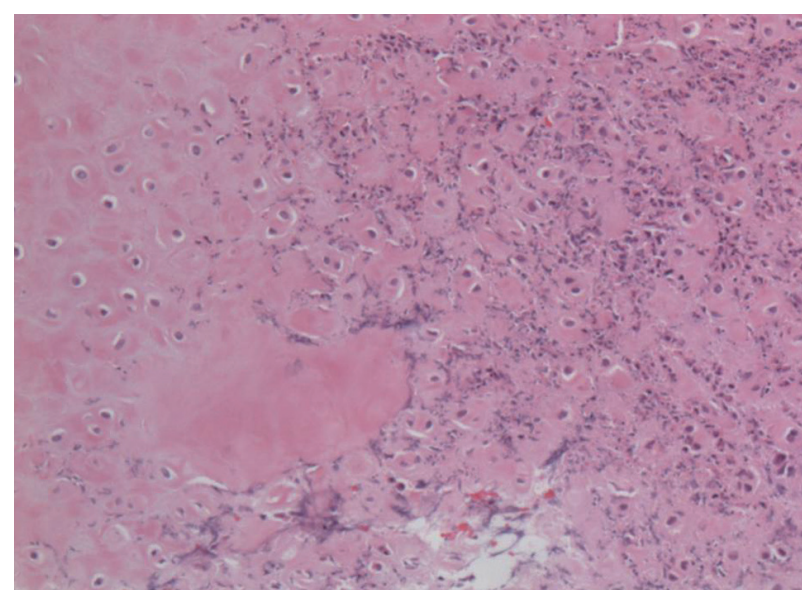

Fig. 4. There is a perichondiral infiltrate of lymphocytes, plasma cells, and neutrophils with acellular foci of the underlying cartilage infiltrations (H \& E stain, $\times 100)$.
할 수 있다고 하였다. 또한 Damiani 등이는 병리조직학적 소 견 없이도 6 가지 진단기준 중 3 개 이상 있을 때, 또는 병리조 직학적 소견과 함께 병변 한 군데만 있거나, 각각 다른 곳의 연골염이 2개 이상 있으면서 부신피질호르몬 또는 dapsone 에 반응이 있는 경우에도 진단이 가능하다고 하였다. 후두, 기관 또는 기관지의 연골염은 예후가 불량하며 재발성 다발성 연골염 사망의 약 $50 \%$ 가 폐렴이나 호흡부전에 의한 것으로 알려져 있다.,11) 기침, 애성, 호흡곤란 및 천명 등의 증상을 호소하며, 심할 경우 기도 폐쇄를 일으킬 수 있어 기도폐색으 로 사망하는 경우도 있다. ${ }^{12}$ 저자들이 치험한 증례에서는 이 개의 염증과 병리조직학적 소견, 그리고 스테로이드제제에 반 응하는 것으로 진단이 가능하였다.

병리조직학적 소견을 보면 헤마톡실린-에오신(hematoxylin-eosin) 염색에서 연골 기질의 호염기성 염색 소실과 연 골막과 주위 결합조직 사이에 경계가 불명확해지고 주로 단핵 구 염증세포 침윤을 볼 수 있다고 한다. 저자들의 경우도 이와 같은 소견을 관찰할 수 있었다(Fig. 3). 그 밖에 재발성 다발 성 연골염의 특징적인 검사 소견은 아니지만 경도의 빈혈, 백 혈구 증가증, 적혈구 침강 속도 증가 등의 소견을 보인다.

임상 경과는 자연 치유에서부터 치명적인 예까지 매우 다 양하며, 사망률은 $28 \%$ 에서 $50 \%$ 까지 보고되고 있고, 젊은 나이에 발병할수록 질병은 더 빠르고 나쁜 경과를 보인다는 보고가 있으며, 기도 협착, 전신혈관염, 현미경적 혈뇨, 빈혈 등이 나쁜 예후를 시사하는 소견이다. Michet 등 ${ }^{13)}$ 은 사망의 원인으로 감염과 심혈관계 합병증 등을 보고하였다.

치료는 증상이 심하지 않은 경우 아스피린과 비스테로이드 성 소염제로 조절되며, 스테로이드제제는 이 질환의 경과를 변경시킨다는 증거는 없지만 급성 증상을 완화시키고 재발을 감소시키는 데 효과적일 수 있다. ${ }^{14)}$ 치료에 반응을 잘 하지 않 는 경우 또는 잦은 재발에 대한 치료 방침은 아직 불명확하지 만 면역억제 및 조절 요법이 고려되는데 이 때 사용하는 약물 들로써는 azathioprine, cyclophosphamide, chlorambucil, 또는 cyclosporin 등과 같은 면역억제제 투여나 혈장반출 법도 보고 되고 있다. ${ }^{15)}$ 저자들의 경우는 면역억제제인 aza-
Fig. 5. Laryngoscopic view of the vocal cords at inspiration $(A)$ and at "e" phonation (B) of the patient. These findings show normal both vocal cord mobility after the treatment.
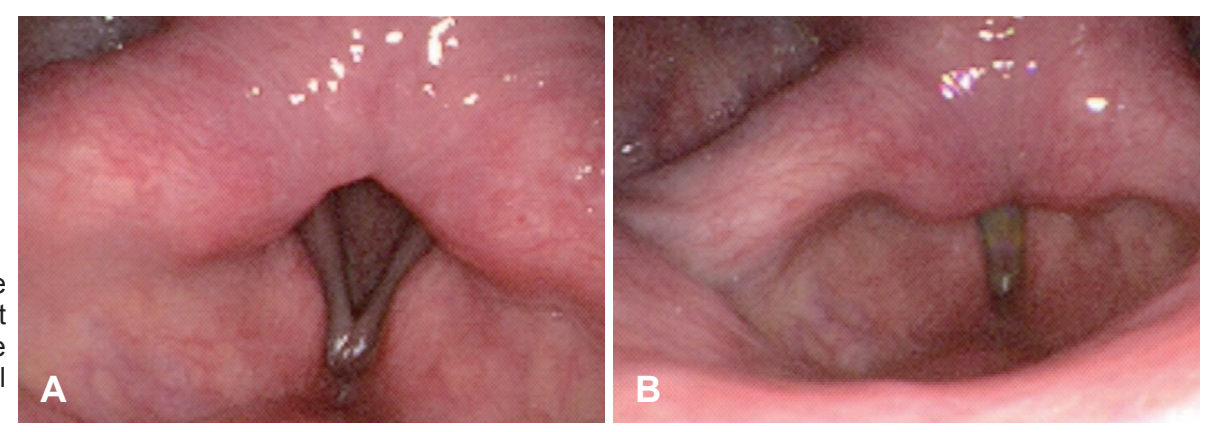
thioprine과 부신피질호르몬인 methylprednisolone로 치료 한 후 환자의 이개 및 성대 고정 증상이 모두 호전되는 것으 로 보아서 성대 고정 역시 재발성 다발성 연골염의 한 증상으 로 발현되었다고 사료된다.

후두와 기관을 침범하는 재발성 다발성 연골염 환자는 호 흡 곤란을 주증상으로 호소한다. ${ }^{3)}$ 하지만, 다른 연골을 침범 하지 않았을 경우, 무증상일 경우가 많다. 또한, 이개염과 다 른 연골염이 동반되지 않은 양측 성대 고정인 환자의 경우, 재 발성 다발성 연골염의 경우를 간과하기 쉽다. 이에 본원에서 치험한 환자에서와 같이 중추성 원인이 배제된 특발성 양측 성대 고정 환자에게서 재발성 다발성 연골염의 가능성을 고려 하는 것이 좋을 것으로 사료된다. 저자들은 양측 성대 고정으 로 인한 호흡 곤란을 첫 주소로 내원한 환자에서, 3 개월 뒤에 이개염과 비배부 연골염이 동반되어 재발성 다발성 연골염으 로 진단되어, 면역억제제 및 스테로이드제제로 치료한 증례를 보고하는 바이다.

\section{REFERENCES}

1) Kim YM, Lee SC, Lee JY, Lee JS. A case of relapsing polychondritis. Korean J Otolaryngol-Head Neck Surg 1993;36(5):1054-9.

2) Lee DH, Kwon SJ, Park JS, Woo CK, Lee CK, Hwang JH, et al. A case of relapsing polychondritis. J Korean Rheum Assoc 1997;4 (2):173-9.

3) Méndez-Flores S, Vera-Lastra O, Osnaya-Juárez J. [Tracheal stenosis as a initial manifestation of relapsing polychondritis. Case report].
Rev Med Inst Mex Seguro Soc 2009;47(6):673-6.

4) Karaman E, Duman C, Cansz H, Ylmaz M, Ibrahimov M. Laryngotracheal reconstruction at relapsing polychondritis. J Craniofac Surg 2010;21(1):211-2.

5) Pearson CM, Kline HM, Newcomer VD. Relapsing polychondritis. $\mathrm{N}$ Engl J Med 1960;263:51-8.

6) Dolan DL, Lemmon GB Jr, Teitelbaum SL. Relapsing polychondritis. Analytical literature review and studies on pathogenesis. Am J Med 1966;41(2):285-99

7) Lahmer T, Knopf A, Treiber M, Heemann U, Thuermel K. Treatment of relapsing polychondritis with the TNF-alpha antagonist adalimumab. Clin Rheumatol 2010;29(11):1331-4.

8) Hussain SS. Relapsing polychondritis presenting with stridor from bilateral vocal cord palsy. J Laryngol Otol 1991;105(11):961-3.

9) McAdam LP, O'Hanlan MA, Bluestone R, Pearson CM. Relapsing polychondritis: prospective study of 23 patients and a review of the literature. Medicine (Baltimore) 1976;55(3):193-215.

10) Damiani JM, Levine HL. Relapsing polychondritis--report of ten cases. Laryngoscope 1979;89(6 Pt 1):929-46.

11) Hughes GB, Kinney SE, Barna BP, Tomsak RL, Calabrese LH. Autoimmune reactivity in Cogan's syndrome: a preliminary report. Otolaryngol Head Neck Surg 1983;91(1):24-32.

12) Spraggs PD, Tostevin PM, Howard DJ. Management of laryngotracheobronchial sequelae and complications of relapsing polychondritis. Laryngoscope 1997;107(7):936-41.

13) Michet CJ Jr, McKenna CH, Luthra HS, O'Fallon WM. Relapsing polychondritis. Survival and predictive role of early disease manifestations. Ann Intern Med 1986;104(1):74-8.

14) Rabuzzi DD. Relapsing polychondritis. Arch Otolaryngol 1970;91 (2):188-94.

15) Zeuner M, Straub RH, Rauh G, Albert ED, Schölmerich J, Lang B. Relapsing polychondritis: clinical and immunogenetic analysis of 62 patients. J Rheumatol 1997;24(1):96-101. 